\title{
Effects of fractal grid on emissions in burner combustion by using fuel-water-air premix injector derived from biodiesel crude palm oil (CPO) base
}

\author{
Mirnah Suardi ${ }^{1,{ }^{*}}$, Amir Khalid $^{1}$, Mohd Azahari Razali ${ }^{1}$, Azwan Sapit ${ }^{1}$ and Shahrin Hisham \\ Amirnordin $^{1}$ \\ ${ }^{1}$ Combustion Research Group (CRG), Centre for Energy and Industrial Environment Studies \\ (CEIES), Faculty of Mechanical and manufacturing Engineering, Universiti Tun Hussein Onn \\ Malaysia, 86400 Parit Raja, Batu Pahat, Johor
}

\begin{abstract}
The alternative fuel is attracted good attention from worldwide especially for renewable and prevention energy such as biodiesel. Biodiesel is one of the hydrocarbon fuels and it has potential for external combustion. As one of the different solutions to these problems, rapid mixing of biodiesel-water-air technique is one of the most significant approaches to improve the combustion and reduce the emissions. The gas emission can be reduced by two methods. First is by improving an injector with fractal and the other is by using a biodiesel-water mixture as an alternative fuel. Mixing of water with fuel in the combustion process is a low cost and effective way. This research used biodiesel Crude Palm Oil (CPO) as fuels in which blended with diesel. This study investigated the effects of water content and equivalence ratio on emissions with the rapid mixing injector. Fuels used are diesel, $\mathrm{CPO}$, $\mathrm{CPO} 10$ and $\mathrm{CPO} 15$ and the exhausts gaseous tested are $\mathrm{CO}, \mathrm{CO}_{2}, \mathrm{HC}$ and $\mathrm{NO}_{\mathrm{X}}$. The gas emissions processes are tested by using the gas analyzer. In this research, water premix of percentage up to $15 \mathrm{vol} \%$ and blending biodiesel ratio was varied from $5 \mathrm{vom} \%-15 \mathrm{vol} \%$. The result shows that increasing of water content will effected decrement of $\mathrm{CO}, \mathrm{CO} 2$ and $\mathrm{HC}$ emissions but increasing the $\mathrm{NO}_{\mathrm{X}}$ emissions.
\end{abstract}

\section{Introduction}

Emission are main issue in the observation of external combustion characteristics. In combustion process, Nitrogen oxide $\left(\mathrm{NO}_{\mathrm{X}}\right)$ reacts with water and other compounds to form various acidic compounds, fine particles and ozone. These pollutants can remain in the air for days or even years. $\mathrm{NO}_{\mathrm{X}}$ are known to be immediately dangerous to human health and environment. Effects of $\mathrm{NO}_{\mathrm{X}}$ are decreases in lung function, resulting in difficulty breathing, shortness of breath, and other symptoms [1-3]. Besides that, $\mathrm{NO}_{\mathrm{X}}$ can

\footnotetext{
*Corresponding author: mirnahsuardi@yahoo.com
} 
be reacted with other pollutants to form toxic chemical as well as contribute to the formation of acid rain. $\mathrm{CO}$ is highly toxic to human body even at lower levels [4].

In the future, the growth of population and economic require more energy and natural resources. Increasing in environmental issues and the cost of fossil fuel has resulted in research on alternative fuel such as biodiesel. Biodiesel as the renewable resource continue to be of interest research in order to achieve a sustainable energy economy thus reducing dependence on fossil fuels. Moreover, worldwide demand on the biodiesel as an alternative fuel is also increasing due to the energy sources crisis.

Advantage of biodiesel is an environmentally friendly fuel, which is one of the clean and renewable energy resources. The fuel is usually made from animal fat or vegetable oil revenue trans-esterification reaction. The oxygen content in biodiesel is $11 \%$ to $15 \%$, which results in increasing the combustion process and reducing the emission from diesel engines [5-6]. The development of biodiesel is increase in particularly for Crude palm oil (CPO). CPO is readily available, safe to store and handle, and most importantly, totally renewable. Its negligible sulphur content compared with diesel's reduces the possibility of acid rain caused by sulphur dioxide emission [7].

CPO can be made into a biodiesel through the process of trans-esterification of triglycerides with methanol. The product of this process is known as palm oil methyl-ester (POME), or palm oil diesel. Studies conducted on POME [7-9] have shown promising results compared with diesel, in terms of combustion process and emission. However, POME is more expensive than CPO, due to the chemical and mechanical processing involved. The interest in $\mathrm{CPO}$ as a diesel substitute stems from its simple production process, which makes it less expensive than POME.

The variation of flame speed with mixture strength roughly follows that of flame temperature. In almost all cases, the maximum value occurs at an equivalence ratio of between 1.05 and 1.10. Notable exceptions to this general rule are hydrogen and carbon monoxide [10-12]. Equivalence ratio $(\phi)$ is an informative paranormal uses normally uses to show the composition of quality where the oxidize fuel is rich, lean or stoichiometry. The equivalence ratio for this research was 0.6 up to 1.4 , which occur in the mixing.

Rapid premixing in the combustion process is to improve the combustion and reduce the gas emission especially $\mathrm{NO}_{\mathrm{X}}$ emissions [13-14]. This study investigated the effect of water content and equivalence ratio on combustion and emissions with the rapid mixing injector. The fuels used are diesel, CPO5, CPO10 and CPO15. The gas emission processes are tested by using the gas analyzer. The exhausts gaseous tested are $\mathrm{CO}, \mathrm{CO}_{2}$, $\mathrm{HC}$ and $\mathrm{NO}_{\mathrm{X}}$. In this research, water premix of percentage up to $15 \mathrm{vol} \%$ and blending biodiesel ratio was varied from $5 \mathrm{vol} \%-15 \mathrm{vol} \%$.

\section{Experimental setup}

The study used three types of biodiesel fuel blends and diesel fuel as a base line. Crude palm oil (CPO) was used to produce the biodiesel blending varied from $5 \mathrm{vol} \%$ ( CPO5) $15 \mathrm{vol} \%$ ( CPO15). The biodiesel blends was prepared using biodiesel blending machine. Fuel properties are shown in Table 1. Figure 1 show the schematic diagram of the experiment and the schematic diagram of rapid mixing injector that being used. The experiment starts by injecting the fuel, air and water into the injector. The injector system uses fuel-air internal rapid mixing concept. The premixing injector was firstly designed by Y. Kidoguchi [10]. The air is pressurized at 0.25 bar. The fuel flow rate and water flow rate are controlled by flow meter and speed controller. Fuel-water-air is mixed at mixing chamber. Then, the mixtures are sprayed out from the nozzle. The mixtures will be ignited using blow torch. The emissions were measured using Autocheck 4/5gas. The Autocheck $4 / 5$ analyser was used to measure the concentration of gas; $\mathrm{HC}, \mathrm{CO}, \mathrm{CO}_{2}, \mathrm{NO}_{\mathrm{X}}$. In this 
study, the composition of the gas being measured is on the exhaust products available on burning furnace. These analyses were inserted at the end of exhaust tail pipe through exhaust probes and the sampling rates for all devices were set 45 seconds. The details of the experimental condition are in Table 2.

Table 1. Properties of fuels.

\begin{tabular}{|c|c|c|c|c|}
\hline \multirow{2}{*}{ Fuel Type } & \multicolumn{4}{|c|}{ Properties } \\
\cline { 2 - 5 } & Density $\left(\mathbf{g} / \mathbf{c m}^{\mathbf{3}}\right)$ & $\begin{array}{c}\text { Kinematic } \\
\text { Viscosity (cP) }\end{array}$ & $\begin{array}{c}\text { Flashpoint } \\
\left({ }^{\mathbf{0}} \mathbf{C}\right)\end{array}$ & $\begin{array}{c}\text { Water } \\
\text { Content } \\
(\mathbf{p p m})\end{array}$ \\
\hline STD & 0.833736 & 3 & 80 & 79.6 \\
\hline CPO5 & 0.837048 & 3 & 91.5 & 120.1 \\
\hline CPO10 & 0.837664 & 2.9 & 92 & 158.6 \\
\hline CPO15 & $0 / 840428$ & 3 & 93.5 & 219 \\
\hline CPO20 & 0.841172 & 3.1 & 94.5 & 294.7 \\
\hline CPO25 & 0.841716 & 3 & 97 & 363.3 \\
\hline CPO30 & 0.845852 & 3.2 & 97.5 & 397.1 \\
\hline CPO35 & 0.844816 & 3.4 & 99.5 & 426.9 \\
\hline CPO40 & 0.848236 & 3.2 & 100 & 558 \\
\hline
\end{tabular}

Table 2. Experimental condition.

\begin{tabular}{|c|c|c|}
\hline \multirow{3}{*}{ Air Compressor } & Model & QUASA HDC-D3050 \\
\hline & Capacity, L/min & 200 \\
\hline & Pressure, $\mathrm{kg} / \mathrm{cm}^{2}$ & 8 \\
\hline \multirow{3}{*}{ Water Pump } & Model & $\begin{array}{l}\text { SFDP1-014-080-22- } \\
\text { Seaflo }\end{array}$ \\
\hline & Voltage, $\mathrm{V}$ & 12 \\
\hline & Flow rate, $\mathrm{L} / \mathrm{min}$ & 5.1 \\
\hline \multirow{3}{*}{ Fuel Pump } & Model & CNY-3805 \\
\hline & Pressure, bar & 3 \\
\hline & Flow rate, $\mathrm{L} / \mathrm{Hr}$ & 100 \\
\hline \multirow{2}{*}{$\begin{array}{l}\text { DC Voltage } \\
\text { Regulator }\end{array}$} & Model & Teletron TC-1206A \\
\hline & Current, A & $64(\max )$ \\
\hline \multirow{5}{*}{$\begin{array}{l}\text { Operating } \\
\text { condition }\end{array}$} & Air Pressure, bar & 0.25 \\
\hline & Air Density, $\mathrm{kg} / \mathrm{m}^{3}$ & 1.16 \\
\hline & Ambient Temperature, $\mathrm{K}$ & 300 \\
\hline & Water Percentage & $0-15 \%$ \\
\hline & Equivalence Ratio & $0.6-1.4$ \\
\hline
\end{tabular}

\section{Results and discussion}

\subsection{Effects of Diesel and CPO 5 vol\% under variants water content on emissions}

Figure 2 shows the concentration of $\mathrm{CO}, \mathrm{CO}_{2}, \mathrm{HC}$ and $\mathrm{NO}_{\mathrm{X}}$ against equivalence ratio at variants water content. As shown in the figure, the $\mathrm{NO}_{\mathrm{X}}$ emissions decrease when the amount of water content is increases between $\phi=1$ and $\phi=1.4$, where pressure of the water weakens the combustion flames and decreases the maximum temperature of the diesel. The $\mathrm{CO}$ and $\mathrm{HC}$ increase drastically for $\phi=0.6$ to $\phi=0.8$ despite little change observed in $\mathrm{CO}_{2}$. As observed, increasing percentage of water content has decrease the $\mathrm{HC}$ as combustion mixture is rich. Highest content of $\mathrm{HC}$ occurs at diesel fuel which is $33 \mathrm{ppm}$ at $\phi=1.4$ followed by CPO5 (5vol\%), CPO10 (10vol\%) and CPO15 (15vol\%). 


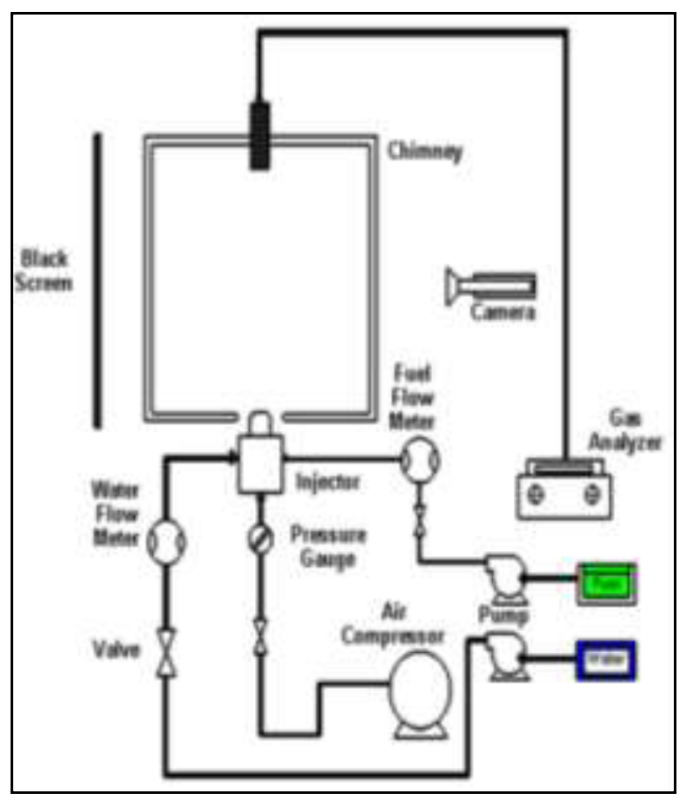

(a)

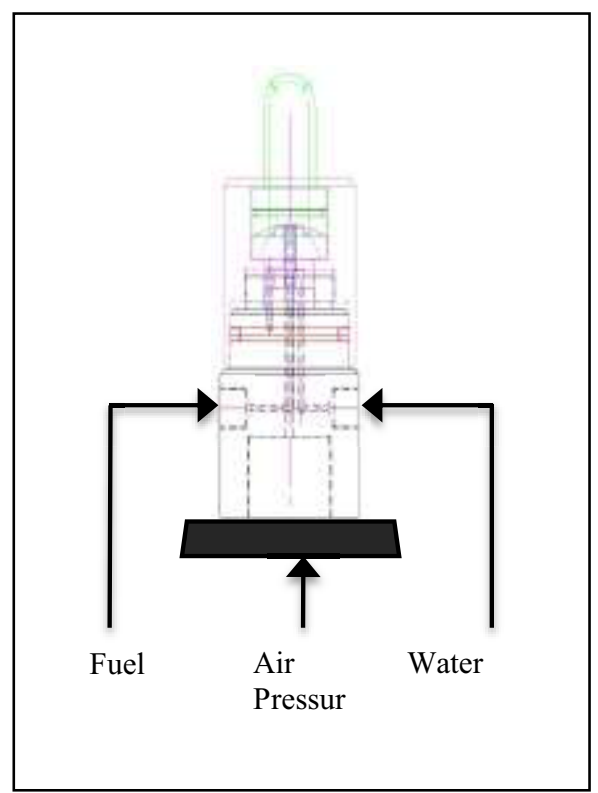

(b)

Fig. 1. (a) Schematic diagram of experiment. ; (b)Schematic diagram of rapid mixing injector.

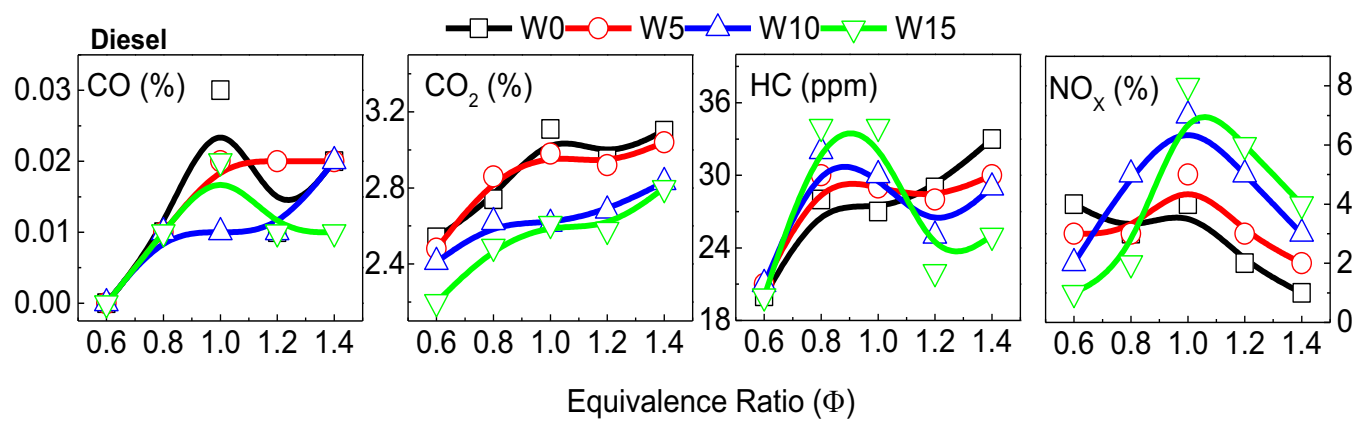

Fig. 2. Effect of water content on Diesel.

Based on the Figure 3, due to the properties of the biodiesel $\mathrm{CPO}$ the $\mathrm{NO}_{\mathrm{X}}$ was increases which by the difference in physical and chemical properties of diesel with biodiesel. Biodiesel CPO base has significant oxygen content compared to the diesel and higher content of oxygen to fuel in combustion which can leads to better complete combustion to produce higher temperature and more $\mathrm{NO}_{\mathrm{X}}$ formation. Biodiesel $\mathrm{CPO}$ also produces lower HC compare to the diesel. This because the homogeneous flame produces less $\mathrm{HC}$ and also helps to increases oxidation as well as reduces the amount of $\mathrm{HC}$ formation. $\mathrm{HC}$ is decreases when the increases of water content which shows similar trend as diesel. The lowest amount of $\mathrm{HC}$ is $21-28 \mathrm{ppm}$ at all water content when $\phi=0.6$. The amount of $\mathrm{CO}_{2}$ also decreases as the water content increases with lower value compared to diesel. Higher amount of oxygen in CPO reduces fuel carbon content which able to reduces to $\mathrm{CO}_{2}$. 


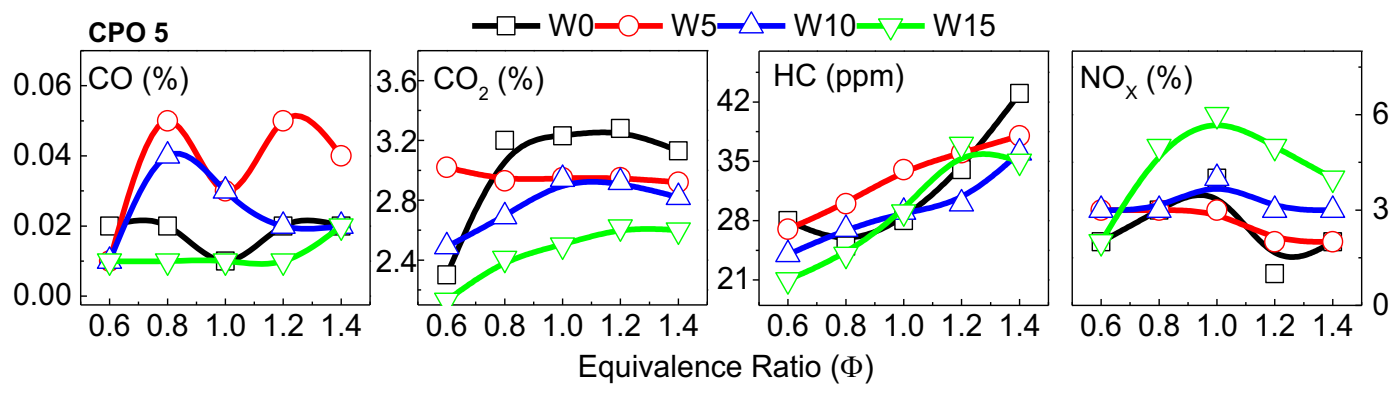

Fig. 3. Effect of water content on CPO5.

\subsection{Effects of high blending ratio of CPO biodiesel and variants water content on emissions}

The effect of water content on CPO 10 is shown in Figure 4. In the figure, increment of water content will affected decreasing of percentage of $\mathrm{CO}_{2}$. Higher oxygen content at $\mathrm{W} 15$ because the more complete combustion occurs when more water is added. CO shows ununiformed trend which CPO10 decreases to lowest for $\mathrm{W} 10$ at equivalence ratio of 1.4 which is $0.01 \%$. The amount of $\mathrm{HC}$ was lowest when increasing of water content. Apparently, increasing of water content will decrease the $\mathrm{NO}_{\mathrm{X}}$ at equivalence ratio of $\phi=0.8$ to 1.0 .
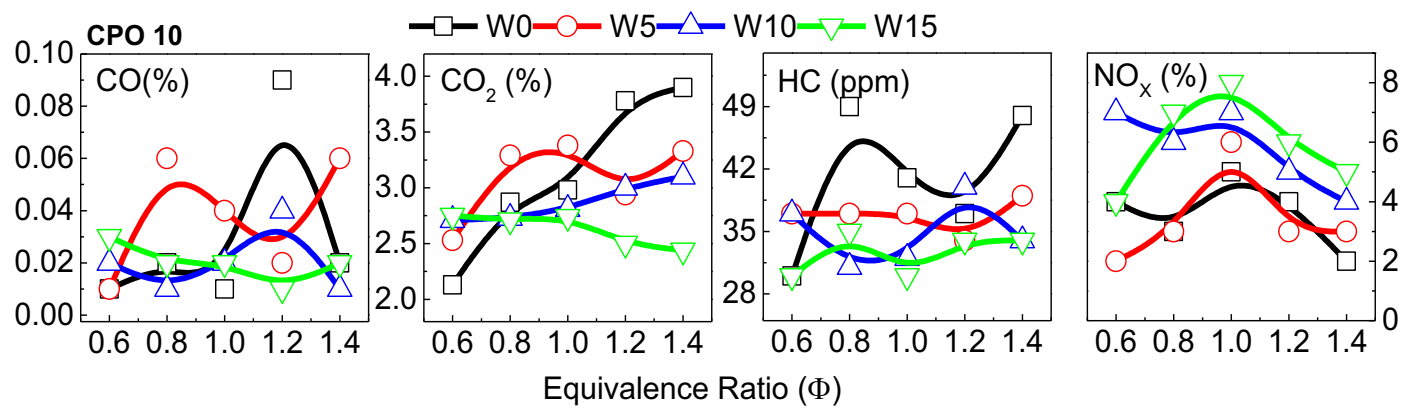

Fig. 4. Effect of water content on CPO10.

Shown in Figure 5 is the effect of water content on $\mathrm{CPO} 15 . \mathrm{CO}, \mathrm{CO}_{2}$ shows similar trend also since $\mathrm{CO}$ is less generated for biodiesel CPO because the concentrated oxygen in biodiesel would enhance the oxygenated fuels like biodiesel and reduce to amount of $\mathrm{CO}$. Biodiesel $\mathrm{CPO}$ also produce lowest $\mathrm{NO}_{\mathrm{X}}$ at W0 which $2 \%$. Considering to the results, increases of percentage of water content, the $\mathrm{HC}$ emission has directly proportional increasing and inversely proportional to the $\mathrm{NO}_{\mathrm{X}}$. 


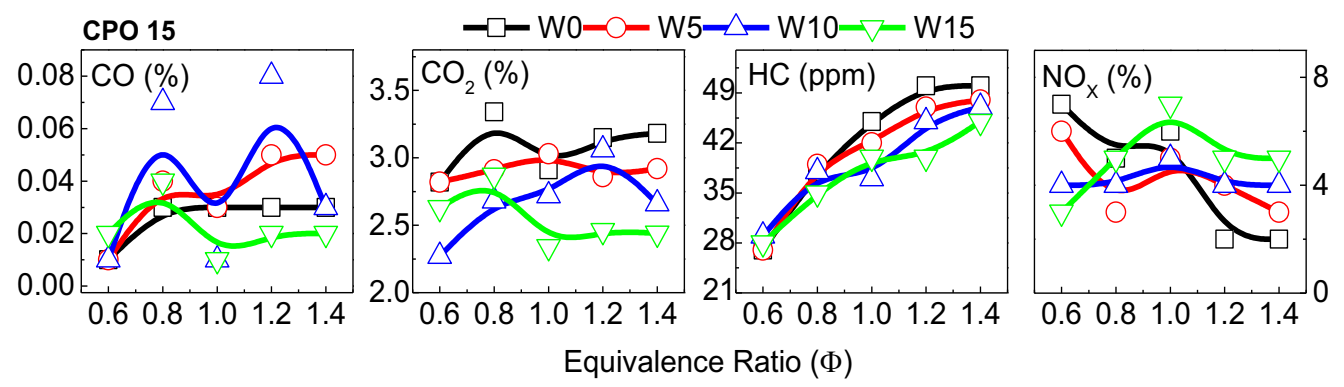

Fig. 5. Effect of water content on CPO15.

\section{Conclusions}

Rapid mixing of biodiesel-air-water technique is one of the most significant approaches to the reduction in emissions, such as nitrogen oxides $\left(\mathrm{NO}_{\mathrm{X}}\right)$. The solution of this issue is by using biodiesel fuel as an alternative fuel from crude palm oil (CPO). In addition, the CPO is one of the most economical options for producing biodiesel due to the biodegradable properties and preserves energy. The emission of $\mathrm{NO}_{\mathrm{X}}$ was significantly lower at high temperatures and low oxygen concentration as compared to low temperatures and high oxygen concentration.

For diesel fuel, the increases of percentage of water content, the $\mathrm{NO}_{\mathrm{X}}$ emission has proportionally decreasing. CPO has significant oxygen content compared to the diesel and higher content of oxygen to fuel in combustion which can leads to better complete combustion to produce higher can temperature and more $\mathrm{NO}_{\mathrm{X}}$ formation. $\mathrm{CPO}$ also produces lower HC compare to the diesel. This because the homogeneous flame produces less $\mathrm{HC}$ and also helps to increases oxidation as well as reduces the amount of $\mathrm{HC}$ formation. $\mathrm{HC}$ increases as the equivalence ratio increases. Observation on $\mathrm{CO}$ emission produces similar trend with $\mathrm{HC}$ and $\mathrm{CO}_{2}$. Higher amount of oxygen in $\mathrm{CPO}$ reduces fuel carbon content which able to reduces to $\mathrm{CO}_{2}$ where temperature show similar trend with diesel.

The authors also would like to thank the Ministry of Higher Education Malaysia for supporting this research under Exploratory Research Grant Scheme (ERGS) vot. E033 and partly sponsored by the Centre for Graduate Studies UTHM.

\section{References}

1. Payri R, Desantes JM, Salvador FJ, Manin J. "Influence On Diesel Injection Characteristics And Behavior Using Biodiesel Fuels". SAE paper 2009-01-0851; 200.(2009)

2. Khalid, A., "Effect of Ambient Temperature and Oxygen Concentration on Ignition and Combustion Process of Diesel Spray", Asian Journal of Scientific Research, Volume 6, Issue 3, 2013, Pages 434-444, Asian Network for Scientific Information, DOI: 10.3923/ajsr.2013.434-444 (2013)

3. A. Khalid, N. Jaat, A. Sapit, A. Razali, B. Manshoor, I. Zaman and A.A. Abdullah, "Performance And Emissions Characteristics Of Crude Jatropha Oil Biodiesel Blends In A Diesel Engine", International Journal of Automotive and Mechanical Engineering (IJAME) ISSN: 2229-8649 (Print); ISSN: 2180-1606 (Online); Volume 11, pp. 2447- 
2457, January-June 2015, DOI: http://dx.doi.org/10.15282/ijame.11.2015.25.0206. (2015)

4. Khalid, A., Tamaldin, N., Jaat, M., Ali, M.F.M., Manshoor, B., Zaman, I., “Impacts of Biodiesel Storage Duration on Fuel Properties and Emissions", Procedia Engineering, Volume 68, 2013, Pages 225-230, Elsevier Ltd, DOI: 10.1016/j.proeng.2013.12.172 (2013)

5. Y. Kidoguchi, T. Yatsufusa, and D. Nakagawa, "Improvement of Emissions and Burning Limits in Burner Combustion using an Injector on the Concept of Fuel-water Internally Rapid Mixing." (2011)

6. T. Yatsufusa, T. Kumura, Y. Nakagawa, and Y. Kidoguchi, "Advantage of Using Water-Emulsified Fuel on Combustion and Emission Characteristics," pp. 2-7. (2009)

7. A. Hussein, A. Hamid, and R. Atan, "Spray characteristics of jet - swirl nozzles for thrust chamber injector," Aerosp. Sci. Technol., vol. 13, no. 4-5, pp. 192-196, (2009)

8. X. Miao, Y. Ju, and X. Wang, "Experimental Investigation on Premixed Combustion in a Diesel Engine with Ultra-Multihole Nozzle," no. 1, (2009)

9. I. Zahmatkesh and M. Moghiman, "From Turbulent Spray Flames," vol. 30, (2006)

10. ArthurH.Lefbvre and D. R. Ballal, Gas Turbine Combustion Alternative Fuels and Emissions. (Third Edition. 2010)

11. Y. Yoshimoto, M. Tsukahara, T. Murayama, "Studies on the Microexplosion of Emulsified Fuels: 1st Report, Effects Of Fuel Properties, Water Contents and Particle Sizes on the Microexplosion on A Hot Surface", J. JSME (B), 55 (519), pages 35383543 (1989)

12. Y. Xu, C.G. Zhu, Y.B. Shen, D. Poulikakos, "Holographic Investigation of Microexplosion in An Emulsified Diesel Oil Spray, Atomization and Sprays", 1993, 3 (2), pages 193-202 (1993)

13. Michele Battistoni, Carlo Nazareno Grimaldi. "Numerical Analysis Of Injector Flow And Spray Characteristics From Diesel Injectors Using Fossil And Biodiesel Fuels". Applied Energy 97, pages 656-666 (2012) 